\title{
Cellular Responses in the Respiratory Tract Following Intranasal administration of Peste des petits Ruminant Vaccine in Goats
}

\author{
Respuestas Celulares en el Tracto Respiratorio Después de la Administración Intranasal \\ de la Vacuna contra la Peste de Pequeños Rumiantes en Cabras
}

Ezeasor, C. V.*; Emikpe, B. O.*; Sabri M. Yussof*; Jagun Afusat* \& Anosa, V. O.*

EZEASOR, C. V.; EMIKPE, B. O.; YUSSOF, S. M.; AFUSAT, J. ANOSA, V. O. Cellular responses in the respiratory tract following intranasal administration of Peste des petits ruminant vaccine in goats. Int. J. Morphol., 31(2):687-692, 2013.

SUMMARY: A trial was conducted to compare the cellular responses in the respiratory tract in intranasal vaccination against caprine Peste des petits ruminant lineage 1 variant virus infection with intramuscular and subcutaneous vaccinations in order to elucidate the mechanism of the protection. Twenty four goats were divided into four equal groups. Group 1 was vaccinated intranasaly, group 2 was vaccinated subcutaneously, and group 3 intramuscularly, while Group 4 was the unvaccinated control group. In each group the vaccinations were carried out once. All goats were challenged intratrachealy with $P P R$ virus at a concentration of 106.5 TCID50 two weeks after vaccination and were euthanised 21 days after the challenge. The bronchoalveolar lavage differential count, bronchial associated lymphoid tissue (BALT) responses were measured using standard techniques. Descriptive Statistics and ANOVA was employed and significance was at $p<0.05$. The exposure also resulted into significant increase in the number and size of BALT as well as the number of lymphocytes in BALT. This study showed the mechanism of the protective effect of intranasal vaccination of $P P R$ vaccine observed with the strong mucosal and defensive cellular responses in the respiratory tract observed than the subcutaneous and intramuscular routes.

KEY WORDS: Cellular responses; Intranasal administration; Peste des petits ruminant vaccine; Goats.

\section{INTRODUCTION}

Peste des petits ruminant $(P P R)$ is a well-known contagious viral disease of domestic and wild small ruminants characterized by pyrexia, mucopurulent nasal and ocular discharges, conjunctivitis, necrotizing and erosive stomatitis, pneumonia, gastroenteritis and, ultimately, death (Diallo, 2007; Emikpe \& Akpavie, 2011). Various studies had focused on the pathology and control of the disease with emphasis on lineage $4 P P R$ virus (Kumar et al., 2004) with very little information on $P P R$ virus $(P P R V)$ from the lineage 1 , which is the circulating strain of $P P R V$ in Nigeria (Emikpe \& Akpavie).

Vaccination against $P P R$, being the only effective means of controlling the disease has experienced various setbacks especially in relation to its effectiveness and ease of application since the conventional approach had been through subcutaneous and intramuscular route of vaccine administration. With the control and prevention of most respiratory diseases being focused on the use of intranasal vaccines which has been shown to induce strong mucosal responses and protection against natural occurring pneumonia in small ruminants (Zamri-Saad et al., 1999), the use for the control of PPR should be accorded due attention.

In order to assess the cellular response in the respiratory tract after vaccination, bronchoalveolar lavage has been found to be handy. Bronchoalveolar lavage (BAL) is useful in diagnosing respiratory system diseases. It is useful in evaluating normal and diseased respiratory system in ruminants (Mohammad et al., 2007). BAL is therefore, a satisfactory method of obtaining samples to evaluate the effectiveness of vaccination regime against respiratory infection. This method had been explored by various researchers (Zamri-Saad et al.) where the local immune response was stimulated following inhalation of antigens. It was observed that the number and size of bronchial

\footnotetext{
* Department of Veterinary Pathology and Microbiology, University of Nigeria, Nsukka, Nigeria

${ }^{* *}$ Department of Pathology and Microbiology, Faculty of Veterinary Medicine, Universiti Putra Malaysia, Malaysia.
} 
associated lymphoid tissue (BALT) was dependent on the antigenic stimulation (Pabst \& Gehrke, 1990). Despite the frequent use of this method in most respiratory infections, there had been dearth of information on this aspect in caprine $P P R$ infection (Emikpe \& Ajisegiri, 2011) especially as it relates to intranasal vaccination which could be explored for the control of the disease. This investigation was therefore designed to evaluate and compare the cellular responses in the respiratory tract when intranasal route of administration of $P P R$ vaccine and the conventional subcutaneous and intramuscular routes were employed in order to determine the route that best induce cellular responses which may in turn facilitate the protection against the pneumonia associated with $P P R$ virus infection in goats.

\section{MATERIAL AND METHOD}

Twenty Four (male and female, n: 12 each) clinically healthy West African dwarf (WAD) goats obtained from a recognized breeding farm, six months of age, and of an average weight of $7 \mathrm{~kg}$ were used for the experiment. They were conditioned for 14 days before the intervention and vital signs (rectal temperature, pulse and respiratory rates) were monitored daily to observe whether they remained afebrile and free of any clinical signs of diseases.

The nasal swabs of the animals were negative for $\mathrm{M}$. hemolytica by cultural isolation and the animals were also confirmed seronegative by Agar gel precipitation technique for antibody to Peste des Petit Ruminant Virus (PPRV). The animals were then randomly assigned to four well partitioned, fly proof pens of the Veterinary Pathology Department, in the experimental animal unit of the Faculty of Veterinary Medicine, University of Ibadan.

Each group had 6 goats (male: 3, female: 3 ). The animals were fed daily with cut grass, supplemented feed and clean drinking water was available ad libitum. The study was independently reviewed and approved by an ethical board of the Faculty of Veterinary Medicine, University of Ibadan and adequate measures were taken to minimize pain or discomfort.

Vaccine. Attenuated 75/1 PPR lineage 1 strain, a homologous $P P R$ vaccine prepared by the National Veterinary research Institute, Vom Nigeria, was used. The vaccine contained freeze dried live attenuated $P P R$ virus grown in Vero cell line a titre of 103.5 TCID50. Each vial was presented as 100 dose freeze dried product in glass vial. The vaccine vial was reconstituted in $100 \mathrm{ml}$ chilled, sterile $0.85 \%$ normal saline and administered either intranasally through a sprayer or intramuscularly and subcutaneously by injection. All goats were monitored twice daily for clinical signs of illness for the period of the experiment.

Experimental procedure. Group 1 was vaccinated intranasally, the exposure was carried out by introducing a single spray of the inoculum directly into the right nostril as earlier described by Effendy et al. (1998) for Mannheimia hemolytica, group 2 was vaccinated subcutaneously, and group 3 intramuscularly, while group 4 was the unvaccinated control. In each group, the vaccinations were carried out once. The infection in the groups was done with $1 \mathrm{ml}$ of the pure culture of $P P R$ virus grown in Baby hamster kidney cell line (BHK) with a titre of 106.5 TCID50 through the intratracheal route as described by Ames et al. (1985) 3 two weeks post vaccination. Three goats were euthanized at two weeks post vaccination and day 21 after challenge using intravenous injection of $90 \mathrm{mg} / \mathrm{kg}$ of $6 \%$ phentobarbitone sodium and the bronchoalveolar lavage was collected as described by Burrells (1985).

Lung lavage sampling. The bronchoalveolar lavage sampling was performed as described by Khin (2009). Following post mortem examination, the trachea together with the lungs were resected and lavaged by introducing 40 $\mathrm{ml}$ of cold sterile phosphate buffered saline (PBS) of $\mathrm{pH} 6.8$ into the lungs through the trachea. This was followed by gentle massage of the lungs before the fluid was re-collected into a beaker container. The lung lavage fluid was then centrifuged at $2000 \mathrm{rpm}$ for 15 minutes to remove the debris and the supernatant was discarded. The sediment was smeared on clean glass slides and stained with Hematoxylin and eosin (H\&E) for cytological examination. The slides were evaluated cytologically; the differential count for each lavage was determined according to Dawson et al. (2005) by counting 400 cells on each of the H\&E stained slides with the reader blinded as to the identity of each goat.

Determination of Bronchial Associated Lymphoid Tisssue (BALT) responses. This was done as described by ZamriSaad \& Effendy (1999). The whole right apical lobe of the lungs were collected and fixed in $10 \%$ buffered formalin before they were cut into five sections at $1 \mathrm{~cm}$ interval and routinely processed and stained with H\&E for histological examinations of the BALT (Anderson et al., 1986). One section from each of the five sites was selected and examined under $\mathrm{x} 4$ objective lens to identify the BALT and classify them as either nodular or aggregate forms (Anderson et al.). The total number of BALT for each slide was recorded. AX 40 objective lens was used to determine the surface area and perimeter of either aggregate or nodular BALT. A polygon function of system software (Micrometrics SE premium) was used to trace the perimeter around the BALT 
and right clicking on the mouse provided the values of the surface area in $\left(\mu \mathrm{m}^{2}\right)$ and perimeter $(\mu \mathrm{m})$ of the selected BALT. A counting function of the system software was used to count manually the lymphocytes within the perimeter of the selected BALT and double-clicking on the mouse gave the total number of lymphocytes within each perimeter. The number and size of BALT and the number of lymphocytes are expressed as an average (Emikpe \& Ajisegiri).

Statistical analysis. All data were analysed statistically using the chi-square, paired t-test and one-way analysis of variance (ANOVA).

\section{RESULTS}

Lung lavage cytology. The lavage fluid recovered ranged from a minimum of $18 \mathrm{ml}$ to a maximum of $23 \mathrm{ml}$. The overall mean volume recovered combining all lung washing was $21.4 \mathrm{ml}$. The overall lavage recovery rate was $54.2 \%$ of the $40 \mathrm{ml}$ of saline solution instilled into the lungs.

The mean differential cell counts for BAL fluid obtained from all the groups of goats are shown in Table I. There were significant differences $(<0.05)$ between the control and treatment groups and also between the treatment groups in the mean values for all the cell types observed.

The pre-vaccination values showed a higher proportion of macrophages, as well as the post vaccinated values in all the groups. Post challenge, the macrophage to neutrophil (M:N) ratio varied greatly amongst the groups, with Group 1 animals (IN vaccination) showing the highest ratio followed by the group 2 animals (SC vaccination), and then the group 3 animals (IM vaccination) and the unvaccinated control.

Bronchial associated lymphoid tissue responses. The average number, type and size of BALT post vaccination was represented in Table II while the average number, type and size of BALT, and the average number of lymphocytes in BALT post challenge are represented in Tables III and IV, respectively. Following $P P R$ vaccination, the average number of BALT was significantly more in Group 1 (IN vaccination) animals than the Group 2 (SC vaccination), Group 3 (IM vaccination) and the control animals with more nodular BALTs than the aggregate type. Also, the average size of nodular BALT was significantly higher in Group 1 animals than the other groups. Following intratracheal challenge of the goats with $P P R$-virus $(P P R V)$, the average number of BALT was significantly more in group 1 (IN vaccinated group) than those observed in SC and IM vaccinated groups. The average number of BALT was $4.25 \pm 2.27$ in IN vaccinated groups compared to $2.36 \pm 1.05,2.10 \pm 1.21$, and $2.17 \pm 1.01$ for the SC vaccinated, IM vaccinated and the unvaccinated (control) groups respectively. Of these, the nodular type of BALT was significantly more than the aggregate type of BALT with $2.75 \pm 1.33$ nodular and $1.50 \pm 0.12$ aggregate for IN vaccinated group, $1.55 \pm 0.68$ nodular and $0.82 \pm 0.08$ aggregates for SC vaccinated group, $1.20 \pm 0.78$ nodular and $0.90 \pm 0.56$ aggregates for IM vaccinated group and finally, $1.34 \pm 0.66$ nodular and $0.83 \pm 0.10$ aggregates for the unvaccinated (control) group. There were no significant differences in the average size of the BALT in surface area and perimeter post challenge (Table III). The average number of lymphocytes showed a significant difference, being more in Group 1 nodular BALT than the other groups (Table IV).

Table I. The average differential cell count of BAL fluid in West African dwarf goats.

\begin{tabular}{llcccc}
\hline & $\begin{array}{c}\text { Macrophage } \\
\text { (Average } \%)\end{array}$ & $\begin{array}{c}\text { Lymphocytes } \\
\text { (Average \%) }\end{array}$ & $\begin{array}{c}\text { Neutrophils } \\
\text { (Average \%) }\end{array}$ & $\begin{array}{c}\text { M:N } \\
\text { Ratio }\end{array}$ \\
\hline CTRL & Pre-inoculation & 70 & 5 & 25 & $2.8: 1$ \\
G1 (IN) & Post inoculation & 56.5 & 3.5 & 40 & $1.4: 1$ \\
& Pre-vaccination & 70 & 5 & 25 & $2.8: 1$ \\
& Post-vaccination & 71 & 4 & 25 & $3: 1$ \\
G2 (SC) & Post-inoculation & 78.5 & 17 & 4.5 & $* 19: 1$ \\
& Pre-vaccination & 70 & 5 & 25 & $2.8: 1$ \\
& Post-vaccination & 62 & 10 & 28 & $3: 1$ \\
G3 (IM) & Post inoculation & 70 & 14.7 & 18 & $4: 1$ \\
& Pre-vaccination & 70 & 5 & 25 & $2.8: 1$ \\
& Post-vaccination & 74 & 11 & 15 & $4: 1$ \\
\hline
\end{tabular}

*Significant $(<0.05)$ 
Table II. Average number, type and size of BALT post vaccination.

\begin{tabular}{|c|c|c|c|c|c|}
\hline GROUP & $\begin{array}{c}\text { Average number } \\
\text { of BALT }( \pm S D)\end{array}$ & NODULAR & $\begin{array}{c}\text { SIZE( surface area } \\
\left.\mu \mathrm{m}^{2}\right)\end{array}$ & Aggregate & $\begin{array}{c}\text { SIZE (surface area } \\
\mu_{\mathrm{m}}^{2)}\end{array}$ \\
\hline Intranasal & $* 3.667 \pm 3.09$ & $* 2.667 \pm 2.49$ & $* 928.35 \pm 383.55$ & $1.00 \pm 0.82$ & $659.28 \pm 492.41$ \\
\hline Subcutaneous & $0.667 \pm 0.47$ & $0.25 \pm 0.43$ & $414.14 \pm 585.7$ & $0.25 \pm 0.43$ & $483.53 \pm 683.81$ \\
\hline Intramuscular & $0.500 \pm 0.500$ & 0 & 0 & $0.500 \pm 0.500$ & $669.85 \pm 669.85$ \\
\hline Control & 0 & 0 & 0 & 0 & 0 \\
\hline
\end{tabular}

*Significant $(<0.05)$

Table III. Average number, type and size (surface area) of BALT post challenge.

\begin{tabular}{lccccc}
\hline GROUP & $\begin{array}{c}\text { AVERAGE } \\
\text { NUMBER OF } \\
\text { BALT( } \pm \text { SD) }\end{array}$ & NODULAR & $\begin{array}{c}\text { SIZE } \\
\left(\text { surface } \mathbf{a r e a ~} \boldsymbol{\mu m}^{2}\right)\end{array}$ & AGGREGATE & SIZE $\left(\mathbf{s u r f a c e}\right.$ area $\left.\boldsymbol{\mu m}{ }^{2}\right)$ \\
\hline 1- IN & $* 4.25 \pm 3.27$ & $2.75 \pm 2.33$ & $175783.27 \pm 179360.2$ & $1.50 \pm 1.12$ & $60544.42 \pm 43484.77$ \\
2- SC & $2.36 \pm 3.05$ & $1.55 \pm 2.68$ & $129447.06 \pm 78469.49$ & $0.82 \pm 0.80$ & $110634.78 \pm 39622.86$ \\
3- IM & $2.10 \pm 3.21$ & $1.20 \pm 1.78$ & $199246.42 \pm 141013.05$ & $0.90 \pm 1.76$ & $62770.44 \pm 45425.88$ \\
CTL & $2.17 \pm 3.01$ & $1.34 \pm 1.66$ & $166879.32 \pm 34646.20$ & $0.83 \pm 1.10$ & $85744.42 \pm 34987.03$ \\
\hline
\end{tabular}

*Significant $(<0.05)$

Table IV. Average number of lymphocytes in BALT post challenge.

\begin{tabular}{lcc}
\hline \multicolumn{1}{c}{ GROUP } & $\begin{array}{c}\text { NODULAR BALT } \\
\text { (number of lymphocytes) }\end{array}$ & $\begin{array}{c}\text { AGGREGATE BALT } \\
\text { (number of lymphocytes) }\end{array}$ \\
\hline 1. INTRANASAL & $* 633.3 \pm 218.4$ & $246.6 \pm 159.8$ \\
2. SUBCUTANEOUS & $399.9 \pm 151.2$ & $303.6 \pm 53.6$ \\
3. INTRAMUSCULAR & $356.1 \pm 103.8$ & $269.3 \pm 41.3$ \\
4. CONTROL & $298.0 \pm 121$ & $116.0 \pm 67$ \\
\hline
\end{tabular}

*Significant $(<0.05)$

\section{DISCUSSION}

This study showed the cellular response in the respiratory tract following intranasal, subcutaneous and intramuscular administration of $P P R$ vaccine in goats.

Bronchoalveolar lavage (BAL) has been explored experimentally in cattle to determine the cellular and humoral responses of the lower respiratory tract to infectious agents (Walker et al., 1980; Wilkie et al., 1980; Kimman et al., 1986) however the cellular changes in the respiratory tracts in caprine $P P R$ has not been previously described.

The BAL differential cell count has been shown to be an accurate predictor of the cellular changes occurring in the lungs (Allen et al., 1996). In this study the differential cell count was used to ascertain the presence or absence of inflammatory response in the lungs of all the groups. The measurement of the non-cellular constituents of BAL fluid (such as immunoglobulins and other secretory components of the immune system) or evaluations of cell function were not attempted; however, the predominance of macrophages in the pre-challenge BAL fluid in this study was in agreement with the findings of various workers (Burrells; Berrag et al., 1997). In the post challenge BAL, the macrophage to neutrophil (M:N) ratio values of the Group 1 (Intranasal vaccination) animals did not differ significantly from the pre-challenge values but differed significantly from those of the other groups (SC, IM and unvaccinated groups) which had a much lower M:N values. This further showed that intranasal vaccination is capable of inducing defensive cellular mechanisms in the respiratory tracts than other routes which further buttress the protective effect of intranasal route. Since the M:N ratio correlate with lung consolidation 
observed, the low M:N values observed in SC, IM and control groups corresponded with high lung consolidation which showed that $\mathrm{M}: \mathrm{N}$ ratio and/ or increased neutrophils in BAL fluid can be used as an index of inflammation in the respiratory tract (Kimman et al.; Allen et al.; Oruç, 2011).

On mucosal response within the respiratory tract, concurrent intranasal and intratracheal exposure to the virus resulted into significant increase in the number of bronchial associated lymphoid tissues (BALT) as well as the number of lymphocytes in BALT (nodular) in the intranasally vaccinated goats than those of the other groups. This is in consonance with the findings of most researchers who reported morphologic and hyperplastic changes following antigenic stimulation or lung infection in BALT (Effendy et al.; Zamri-Saad et al.; Emikpe \& Ajisegiri).

In this investigation, the number and size of BALT were significantly increased $(\mathrm{p}<0.05)$ in intranasal group post vaccination. This observation may be due to antigenic stimulation of the lymphoid aggregates for mucosal secretory defense mechanisms as reported by other workers (Pabst \& Gehrke; Barman et al., 1996; Khin et al., 2009).
The trends observed in the cellular response in the respiratory tract further showed that intranasal route of $P P R$ vaccine administration is efficient in inducing strong cellular defensive mechanism against the development of pneumonia in $P P R$.

In conclusion, this study has clearly revealed that intranasal $P P R$ vaccination is more efficient in inducing protective mechanism in the respiratory tract than the subcutaneous, intramuscular routes and this was achieved by strong mucosal response and induction of defensive cellular response in the respiratory tract. This further substantiated the safety and efficacy of intranasal route for $P P R$ vaccine in PPR endemic zones especially in Subsaharan Africa.

\section{ACKNOWLEDGEMENT}

The authors are grateful to Prof. M. Zamri-Saad of Department of Pathology and Microbiology, Fakulti Perubatan Veterinar, Universiti Putra Malaysia for his comments and advice that led to this investigation.

EZEASOR, C. V.; EMIKPE, B. O.; YUSSOF, S. M.; AFUSAT, J. ANOSA, V. O. Respuestas celulares en el tracto respiratorio después de la administración intranasal de la vacuna contra la peste de pequeños rumiantes en cabras. Int. J. Morphol., 31(2):687-692, 2013.

RESUMEN: Se realizó un ensayo para comparar las respuestas celulares en las vías respiratorias después de la vacunación intranasal contra la variante caprina de la infección del virus peste de pequeños rumiantes linaje 1 con vacunas intramusculares y subcutáneas con el fin de dilucidar el mecanismo de protección. Veinticuatro cabras fueron divididas en cuatro grupos iguales. El Grupo 1 fue vacunado por vía intranasal, el grupo 2 vía subcutánea, el grupo 3 vía intramuscular y el grupo 4 control no vacunado. En cada grupo se vacunó sólo una vez. Todas las cabras fueron expuestas al virus peste de pequeños rumiantes por vía intratraqueal a una concentración de 106.5 TCID50 2 semanas después de la vacunación, y fueron sometidos a eutanasia 21 días después. Se midieron el recuento diferencial del lavado broncoalveolar y las respuestas de los tejidos linfoides asociados bronquios (BALT) utilizando técnicas estándar. Los resultados se evaluaron por estadística descriptiva y ANOVA, con una significación p<0,05. La exposición también mostró un aumento significativo en el número y tamaño del BALT, así como el número de linfocitos en este. El estudio mostró que el mecanismo del efecto protector de la vacunación intranasal contra el virus peste de pequeños rumiantes posee una respuesta mucosa y celular defensiva en el tracto respiratorio mayor que la observada por vacunación vía subcutánea e intramuscular.

PALABRAS CLAVE: Respuestas celulares; Administración intranasal; Vacuna peste de pequeños rumiantes; Cabras.

\section{REFERENCES}

Allen, J. W.; Viel, L.; Bateman, K. G.; Rosendal, S. \& Shewen, P. E. Cytological findings in bronchoalveolar lavage fluid from feedlot calves: associations with pulmonary microbial flora. Can. J. Vet. Res., 56(2):122-6, 1992.

Ames, T. R.; Markham, R. J.; Opuda-Asibo, J.; Leininger, J. R. \& Maheswaran, S. K. Pulmonary response to intratracheal challenge with Pasteurella haemolytica and Pasteurella multocida. Can. J. Comp. Med., 49(4):395-400, 1985.
Anderson, M. L.; Moore, P. F.; Hyde, D. M. \& Dungworth, D. L. Bronchus associated lymphoid tissue in the lungs of cattle: relationship to age. Res. Vet. Sci., 41(2):211-20, 1986.

Barman, N. N.; Bhattacharyya, R.; Upadhyaya, T. N. \& Baishya, G. Development of bronchus-associated lymphoid tissue in goats. Lung, 174(2):127-31, 1996.

Berrag, B.; Rhalem, A.; Sahibi, H.; Dorchies, P. \& Cabaret, J. 
Bronchoalveolar cellular responses of goats following infections with Muellerius capillaris (Protostrongylidae, Nematoda). Vet. Immunol. Immunopathol., 58(1):77-88, 1997.

Burrells, C. Cellular and humoral elements of the lower respiratory tract of sheep. Immunological examination of cells and fluid obtained by bronchoalveolar lavage of normal lungs. Vet. Immunol. Immunopathol., 10(2-3):225-43, 1985.

Dawson, S.; Else, R. W.; Rhind, S. M. \& Collie, D. D. Diagnostic value of cytology of bronchoalveolar fluid for lung diseases of sheep. Vet. Rec., 157(15):433-6, 2005.

Diallo, A.; Minet, C.; Le Goff, C.; Berhe, G.; Albina, E.; Libeau, G.; et al. The threat of peste des petits ruminants: progress in vaccine development for disease control. Vaccine, 25(30):5591-7, 2007.

Effendy, A. W.; Zamri-Saad, M.; Maswati, M. A.; Ismail, M. S. \& Jamil, S. M. Stimulation of the bronchus-associated lymphoid tissue of goats and its effect on in vitro colonization by Pasteurella haemolytica. Vet. Res. Commun., 22(3):147-53, 1998.

Emikpe B. O. \& Akpavie, S. O. The clinicopathologic effects of Peste des petits ruminants virus in experimentally infected West African dwarf goats. Small Ruminant Res., 95(2):168-73, 2011.

Emikpe B. O. \& Ajisegiri W. A. The response of bronchial associated lymphoid tissue to intratracheal administration of Peste des Petit Ruminants Virus and its co-infection with Mannheimia hemolytica in goats. Int. J. Morphol., 29(4):1099-103, 2011.

Khin, M. N. Bovine mucosal immune response to intranasal exposure with live Pasteurella multocida B:2. PhD Thesis, Faculty of Veterinary Medicine, Universiti Putra Malaysia, 2009.

Khin, M. N.; Zamri-Saad, M.; Noordin, M. M. \& Effendy, A. W. M. Effect of intranasal attenuated Pasteurella multocida B:2 on haemorrhagic septicaemia in calves. Online J. Vet. Res., 13(2):65-72, 2009

Kimman, T. G.; Zimmer, G. M.; Straver, P. J. \& de Leeuw, P. W. Diagnosis of bovine respiratory syncytial virus infections improved by virus detection in lung lavage samples. Am. J. Vet. Res., 47(1):143-7, 1986.

Kumar, P.; Tripathi, B. N.; Sharma, A. K.; Kumar, R.; Sreenivasa, B. P.; Singh, R. P.; et al. Pathological and immunohistochemical study of experimental peste des petits ruminants virus infection in goats. J. Vet. Med. B Infect. Dis. Vet. Public Health, 51(4):1539, 2004

Mohammadi G. R.; Nazifi S.; Rezakhani A. \& Esmailnejad Z. Effect of transportation stress on blood and bronchoalveolar lavage fluid components in calves. Comp. Clin. Pathol., 16:85-95, 2007.

Oruç, E. Cytopathologic studies in sheep pneumonias. Eurasian J. Vet. Sci., 27(1):67-71, 2011.

Pabst, R. \& Gehrke, I. Is the bronchus-associated lymphoid tissue
(BALT) an integral structure of the lung in normal mammals, including humans? Am. J. Respir. Cell Mol. Biol., 3(2):131-5, 1990.

Walker, R. D.; Corstvet, R. E.; Lessley, B. A. \& Panciera, R. J. Study of bovine pulmonary response to Pasteurella haemolytica: specificity of immunoglobulins isolated from the bovine lung. Am. J. Vet. Res., 41(7):1015-23, 1980.

Wilkie, B. N.; Markham, R. J. \& Shewen, P. E. Response of calves to lung challenge exposure with Pasteurella haemolytica after parenteral or pulmonary immunization. Am. J. Vet. Res., 41(11):1773-8, 1980.

Zamri-Saad, M. \& Effendy, A. W. The effects of dexamethasone on the response of bronchus-associated lymphoid tissue to intranasal administration of formalin-killed Pasteurella haemolytica A2 in goats. Vet. Res. Commun., 23(8):467-73, 1999.

Zamri-Saad, M.; Effendy, A. W.; Israf, D. A. \& Azmi, M. L. Cellular and humoral responses in the respiratory tract of goats following intranasal stimulation using formalin-killed Pasteurella haemolytica A2. Vet. Microbiol., 65(3):233-40, 1999.

\section{Correspondence to:}

Emikpe, B. O.

Department of Veterinary Pathology

University of Ibadan

Ibadan

Oyo State

NIGERIA

Email: banabis2001@yahoo.com

bo.emikpe@mail ui.edu.ng

Received: 23-07-2012

Accepted: 24-09-2012 